\title{
Serum soluble interleukin-2 receptor levels in familial Mediterranean fever
}

\author{
Eren Erken, Ramazan Güneşaçar, Süleyman Özbek, Kamuran Konca
}

\begin{abstract}
Objective-To investigate serum soluble interleukin-2 receptor (sIL-2R) in familial Mediterranean fever (FMF) and assess its role in acute FMF crisis.

Methods-Serum sIL-2R concentrations were measured in patients with FMF during acute crises and during inactive periods of the disease, using an immunoenzymatic assay kit. Twenty four FMF patients during acute crisis (active FMF), 17 patients with inactive FMF, 24 healthy controls, and 20 active patients with rheumatoid arthritis (as a disease control group) were studied.

Results-Serum sIL-2R concentrations were increased during an acute FMF crisis compared with the values in inactive FMF patients and healthy controls $(P=$ 0.0105 and $P=0.0012$ respectively), while there was no significant difference between the mean values in active FMF and rheumatoid arthritis patients $(P=$ 0.7325). In 14 of the FMF group whose blood samples were available in both active and inactive phases, sIL-2R concentrations were significantly higher in an acute attack than in an attack-free period $(P=0.027)$.

Conclusions-An increase in sIL-2R may be a result of hyperreactivity of IL-2R-expressing cells during an acute inflammatory attack of FMF.
\end{abstract}

(Ann Rheum Dis 1996;55:852-855)

Familial Mediterranean fever (FMF) is an autosomal recessive disorder of unknown aetiology which is characterised by recurrent painful attacks of polyserositis (peritonitis, pleuritis) usually accompanied by fever. The disease is seen mostly in Mediterranean countries and most commonly affects Sephardic Jews, Armenians, Levantine Arabs, and Anatolian Turks. ${ }^{1}$

Many studies have been carried out in an

Department of RheumatologyImmunology, Faculty of Medicine, Cukurova University, 01330 Balcal, Adana, Turkey E Erken R Güneşaçar $S$ Özbek

K Konca

Correspondence to: Dr Eren Erken.

Accepted for publication 12 August 1996 attempt to determine the mechanisms of the inflammatory attacks in FMF. Several non-specific changes in immunological function such as impaired tumour necrosis factor (TNF $\alpha$ ) production by peripheral blood mononuclear cells, ${ }^{2}$ decreased interleukin-1 (IL-1) activity of peripheral monocytes, ${ }^{3}$ raised serum acute phase proteins such as $C$ reactive protein and serum amyloid $\mathrm{A},{ }^{46} \mathrm{C} 5 \mathrm{a}$ inhibitor deficiency in peritoneal fluid ${ }^{7}$ and synovial fluid, ${ }^{8}$ and decreased in vitro suppressor cell function ${ }^{9}$ have been shown in patients with FMF.

Interleukin-2 (IL-2) is an autocrine growth factor that is secreted by activated $T$ lymphocytes. It has an essential role in clonal $\mathrm{T}$ cell proliferation, together with its effects on cytokine production and the functional properties of $B$ cells, macrophages, and natural killer (NK) cells. ${ }^{10}$ Activated T cells, B cells, NK cells, large granular lymphocytes, medullary thymocytes, and macrophages express interleukin-2 receptors (IL-2R) on their surface. The IL-2 receptors are composed of $\alpha, \beta$, and $\gamma$ heterodimers. Following lymphocyte activation the polypeptide chain, in addition to being expressed on the cell surface, is released in soluble form; thus, by detection of soluble $\mathrm{IL}-2$ receptors (sIL$2 \mathrm{R}$ ) in serum, lymphocyte activation can be assessed. ${ }^{10-11}$

The physiological significance of circulating soluble IL-2R remains unknown. It may be merely a marker of cellular immune activation or subserve an important immunoregulatory function. Soluble IL-2R has been shown to be capable of efficiently binding IL-2; it could therefore act by binding to free IL-2, either to inhibit its interaction with cell surface receptors or alteratively to function as a transport protein. ${ }^{12}$

Raised concentrations of serum sIL-2R have been reported in patients with acquired immune deficiency syndrome, human $\mathrm{T}$ cell lymphocytotrophic virus 1 leukaemia, hairy cell leukaemia, leprosy, and in patients with chronic renal failure who are undergoing haemodialysis. ${ }^{13}$ Serum sIL-2R concentrations have also been found to be raised in patients with active systemic lupus erythematosus and active rheumatoid arthritis. ${ }^{13-14}$ Since raised serum sIL-2R has been found in such inflammatory diseases, we reasoned that it might also be increased in the sera of the patients with FMF during acute attacks. We measured the serum levels of sIL-2R and determined whether they correlated with acute attacks of the disease.

\section{Methods}

Twenty seven patients with FMF (eight male, 19 female; mean age 29.4 years, range 6 to 59) were included in this study. Twenty four were in the first 48 hours of an acute attack of fever and peritonitis, while three were in the inactive phase when they were first admitted. In 14 of these 24, samples from both active and inactive phases 
Table 1 Some clinical and laboratory features of patients with active familial Mediterranean fever (FMF)

\begin{tabular}{|c|c|c|c|c|c|c|c|c|c|}
\hline $\mathrm{No} o^{*}$ & Age & Sex & $\begin{array}{l}\text { Family } \\
\text { history }\end{array}$ & $\begin{array}{l}\text { Duration of } \\
\text { disease } \\
\text { (years) }\end{array}$ & $\begin{array}{l}\text { Abdominal } \\
\text { pain }\end{array}$ & Fever & Arthralgia & $\begin{array}{l}E S R^{* *} \\
\mathrm{~mm} / \text { hour }\end{array}$ & $\begin{array}{l}C R P^{\star \star *} \\
m g l^{1}\end{array}$ \\
\hline 1 & 6 & F & - & 2 & + & + & + & 33 & 48 \\
\hline 2 & 22 & F & + & 18 & + & + & + & 46 & 192 \\
\hline 3 & 24 & $\mathrm{~F}$ & - & 5 & + & + & + & 24 & 48 \\
\hline 4 & 59 & $\mathrm{~F}$ & - & 9 & + & + & + & 32 & 192 \\
\hline 5 & 43 & $\mathbf{F}$ & - & 27 & + & + & + & 23 & 96 \\
\hline 6 & 34 & $\mathrm{~F}$ & + & 24 & + & + & + & 18 & 0 \\
\hline 7 & 29 & $\mathrm{~F}$ & + & 12 & + & + & + & 21 & 0 \\
\hline 8 & 23 & $\mathrm{~F}$ & - & 7 & + & + & + & 16 & 48 \\
\hline 9 & 31 & $\mathrm{~F}$ & - & 7 & + & + & + & 36 & 192 \\
\hline 10 & 46 & $\mathrm{~F}$ & - & 6 & + & + & + & 28 & 0 \\
\hline 11 & 30 & F & + & 8 & + & + & + & 18 & 48 \\
\hline 12 & 37 & $\mathbf{F}$ & + & 32 & + & + & + & 28 & 6 \\
\hline 13 & 22 & $\mathbf{M}$ & - & 6 & + & + & + & 34 & 48 \\
\hline 14 & 26 & $\mathbf{M}$ & - & 3 & + & + & + & 44 & 96 \\
\hline 15 & 30 & F & - & 6 & + & + & + & 31 & 96 \\
\hline 16 & 21 & $\mathbf{F}$ & - & 6 & + & + & + & 29 & 0 \\
\hline 17 & 29 & F & - & 9 & + & + & + & 34 & 96 \\
\hline 18 & 33 & $\mathbf{F}$ & + & 15 & + & + & + & 26 & 6 \\
\hline 19 & 18 & $\mathbf{F}$ & + & 4 & + & + & + & 31 & 0 \\
\hline 20 & 28 & $F$ & + & 12 & + & + & + & 39 & 192 \\
\hline 21 & 28 & $M$ & - & 11 & + & + & + & 32 & 12 \\
\hline 22 & 38 & M & + & 8 & + & + & + & 30 & 96 \\
\hline 23 & 34 & $M$ & - & 18 & + & + & + & 35 & 0 \\
\hline 24 & 23 & M & + & 13 & + & + & - & 26 & 6 \\
\hline
\end{tabular}

Patients Nos 1-14 are common in both active and
sedimentation rate, $\star \star \star$
CRP: $C$ reactive protein

were available. In total, 17 blood samples were available from patients in the inactive phase of the disease. Inactive patients were on $1 \mathrm{mg}$ colchicine prophylaxis daily, while none of the acute group was taking colchicine at the onset of the crisis. Erythrocyte sedimentation rate (ESR) and serum $\mathrm{C}$ reactive protein measurements were also done in all cases. Some clinical and laboratory features of active and inactive FMF patients are shown in tables 1 and 2 respectively.

Twenty four healthy controls (six male, 18 female; mean age 29.7 years, range 18 to 43 ) and 20 patients with active seropositive rheumatoid arthritis (20 female; mean age 36.8 years, range 29 to 60 ) were also included in the study as normal and disease controls respectively. The Lansbury activity index was used for the assessment of clinical activity in patients with rheumatoid arthritis. ${ }^{15}$

Serum samples were obtained from venous blood and frozen immediately. Aliquots of the samples were stored frozen at $-30^{\circ} \mathrm{C}$ until the assays were done. Serum sIL-2R measurement was done using an immunoenzymatic assay kit

Table 2 Some clinical and laboratory features of patients with inactive familial Mediterranean fever (FMF)

\begin{tabular}{lcclcc}
\hline$N^{*}$ & Age & Sex & $\begin{array}{l}\text { Family } \\
\text { history }\end{array}$ & $\begin{array}{l}\text { Duration of } \\
\text { disease (years) }\end{array}$ & $\begin{array}{c}C R P^{\star *} \\
m g l^{1}\end{array}$ \\
\hline 1 & 6 & F & - & 2 & 6 \\
2 & 22 & F & + & 18 & 96 \\
3 & 24 & F & - & 5 & 0 \\
4 & 59 & F & - & 9 & 0 \\
5 & 43 & F & - & 27 & 6 \\
6 & 34 & F & + & 24 & 0 \\
7 & 29 & F & + & 12 & 0 \\
8 & 23 & F & - & 7 & 0 \\
9 & 31 & F & - & 7 & 48 \\
10 & 46 & F & - & 6 & 6 \\
11 & 30 & F & + & 8 & 24 \\
12 & 37 & F & + & 32 & 0 \\
13 & 22 & M & - & 6 & 0 \\
14 & 26 & M & - & 3 & 24 \\
15 & 17 & F & + & 13 & 6 \\
16 & 31 & M & - & 21 & 12 \\
17 & 35 & M & + & 26 & 48 \\
\hline Patients Nos 1-14 are common in both active and inactive
\end{tabular}

FMF groups, ${ }^{\star \star} \mathrm{CRP}$ : $\mathrm{C}$ reactive protein.
(Medgenix, Fleurus, Belgium). Minimum detectable sIL-2R concentration of the kit was $24 \mathrm{U} \mathrm{ml}^{-1}$.

STATISTICAL ANALYSIS

Medians and interquartile ranges were calculated for each group. Differences between sIL-2R values were evaluated by the Mann Whitney U test or the Wilcoxon matched pairs test. Associations between sIL-2R, C reactive protein, and ESR were tested by correlation analysis.

\section{Results}

Medians for sIL-2R concentrations in the patients with FMF were as follows: 24 active patients: $1450 \mathrm{U} \mathrm{ml}^{-1}$ (range: $0-4200 \mathrm{U} \mathrm{ml}^{-1}$, interquartile range: $\left.611.25 \mathrm{U} \mathrm{ml}^{-1}\right) ; 17$ inactive patients: $230 \mathrm{U} \mathrm{ml}^{-1}$ (range: $0-3200 \mathrm{U} \mathrm{ml}^{-1}$, interquartile range: $712.5 \mathrm{U} \mathrm{ml}^{-1}$ ).

Median sIL-2R concentrations of the healthy controls were $830 \mathrm{U} \mathrm{ml}^{-1}$ (range: 420-1300 $\mathrm{U} \mathrm{ml}^{-1}$, interquartile range: $288.75 \mathrm{U}$ $\mathrm{ml}^{-1}$ ); those of patients with active rheumatoid arthritis were $1222.5 \mathrm{U} \mathrm{ml}^{-1}$ (range: $667-2601$ $\mathrm{U} \mathrm{ml}^{-1}$, interquartile range: $332.37 \mathrm{U} \mathrm{ml}^{-1}$ ).

The distribution of sIL-2R concentrations in patients with active and inactive patients FMF, patients with active rheumatoid arthritis, and healthy controls are shown in fig 1 .

Serum sIL-2R concentrations were significantly higher in the active FMF group than in the healthy controls $(P=0.0012$, Mann Whitney U test), while there was no significant difference between the inactive group and normal controls $(P=0.11$, Mann Whitney $U$ test). There was also a significant difference between the sIL-2R levels of 24 patients with active and 17 with inactive $F M F(P=0.0105$, Mann Whitney U test).

Figure 2 shows sIL-2R concentrations of the 14 patients with FMF whose sera were available in both active and inactive phases. There was a significant difference between sIL-2R concentrations of these patients in their active and inactive phases $(P=0.027$, Wilcoxon test). Twenty patients with active rheumatoid arthritis also had significantly raised serum sIL-2R concentrations when compared with 24 healthy controls $(P=$ 0.0001 , Mann Whitney U test).

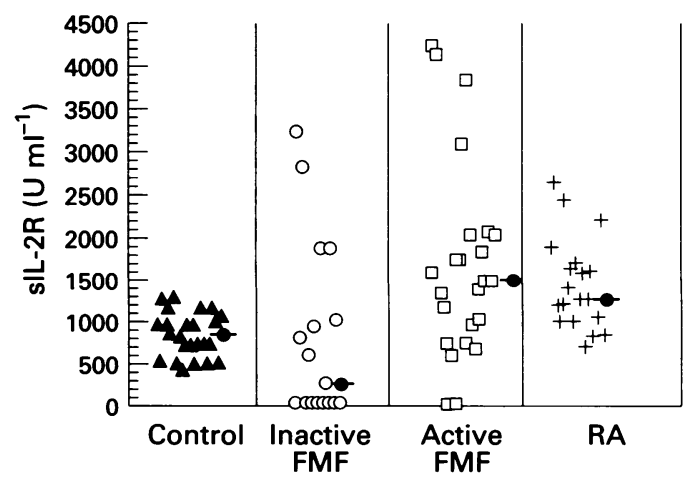

Figure 1 Distribution of soluble IL-2R (sIL-2R) concentrations in patients with inactive and active familial Mediterranean fever (FMF) compared with those of healthy controls and patients with active rheumatoid arthritis $(R A)$. 


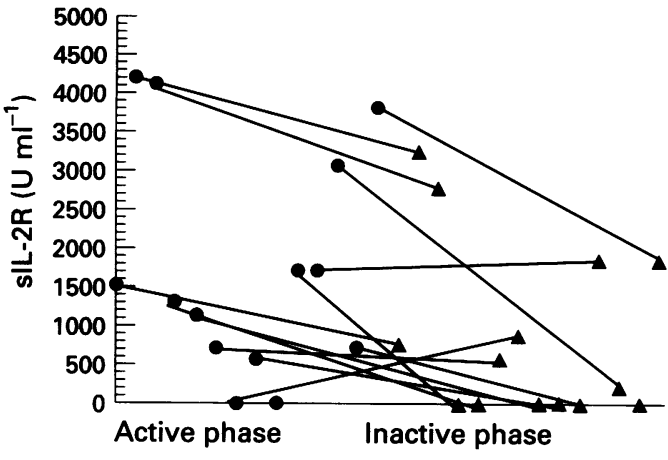

Figure 2 Serum soluble IL-2R (sIL-2R) concentrations of 14 patients with $F M F$ in both active and inactive phases.

Serum sIL-2R concentrations were found to be very high in four patients with inactive FMF (figs 1 and 2). These patients had no specific clinical symptoms during the inactive phase. Interestingly, during an acute crisis their sIL-2R concentrations were even higher than during the inactive periods (fig 2), though again, no specific clinical symptoms were noted.

No significant correlation was found between sIL-2R and $\mathrm{C}$ reactive protein concentrations in patients with active or inactive FMF $(r=0.257, \mathrm{P}>0.05$, and $r=$ $0.088, P>0.05$, respectively). However there was a significant correlation between ESR and sIL-2R concentrations in patients with active FMF $(r=0.552, \mathrm{P}<0.01)$. The ESR in patients with active FMF also correlated significantly with $C$ reactive protein $(r=0.414$, $P<0.05)$.

There was no significant difference in sIL-2R concentrations between patients with active FMF (24) and patients with active rheumatoid arthritis $(20)(P=0.732$, Mann Whitney $\mathrm{U}$ test).

\section{Discussion}

High serum concentrations of sIL-2R have been reported in patients with various autoimmune diseases, including rheumatoid arthritis $^{1112}$ and systemic lupus erythematosus. ${ }^{13}$ Correlation between sIL-2R levels and disease activity have also been described in these diseases. $^{1314}$

Although its immunopathogenesis remains unknown, FMF is a disease characterised by inflammatory attacks of serosal membranes and joints accompanied by fever. The trigger that starts the inflammatory attacks is also unknown. A genetic defect that renders the patients susceptible to an unknown stimulus initiating an inflammatory response could be responsible for the pathogenesis of acute attacks in FMF. In our study, serum sIL-2R concentrations were significantly raised in patients with FMF during acute attacks (active phase) when compared with attack-free periods (inactive phase). There was also a significant difference between sIL-2R levels of FMF patients and healthy controls. Similar results were also obtained in our 20 patients with rheumatoid arthritis. There have been several reports that serum concentrations of sIL-2R correlate with disease activity in rheumatoid arthritis. ${ }^{113}$ Our results indicate that sIL-2R concentrations might reflect the clinical activity in FMF patients also, since we found a significant correlation between sIL-2R concentrations and ESR, which is usually raised during an FMF crisis.

The function of soluble IL-2R is uncertain, but it has been postulated that it may downregulate cellular immune responses by competing with transmembrane binding IL-2R to bind IL-2 ${ }^{14}$ Ilfeld et al reported a decrease in suppressor cell function in FMF. ${ }^{9}$ In one preliminary study by Melamed et al, the number of suppressor $T$ cells and helper $T$ cells was found to be decreased while NK cell numbers were increased. ${ }^{16}$ However, these studies showing immune regulation imbalance in FMF patients need to be confirmed.

Our data showing raised sIL-2R concentrations in acute FMF crises are another demonstration of immune abnormality in this condition. This elevation could be a result of hyperreactivity of IL-2R expressing cells such as T cells, B cells, NK cells, or macrophages, responding to any trigger that starts an acute attack in FMF.

IL-2 is transiently expressed on activated T cells. It is not expressed on resting $\mathrm{T}$ cells, but induced to maximum levels within two to three days after $\mathrm{T}$ cell activation. ${ }^{10}$ In order to examine the relation between sIL-2R elevation and $T$ cell activation during an FMF crisis, further studies need to be done, including investigation of IL-2R (CD25) expression on lymphocytes during attacks and during inactive periods of FMF, and its correlation with SIL-2R.

All of our patients in the inactive phase were receiving colchicine prophylaxis. It is not known whether colchicine affects sIL-2R concentrations. sIL-2R measurement was available in only two inactive patients without colchicine prophylaxis, who were not included in this study (one with an sIL-2R value of 420 $\mathrm{U} \mathrm{ml}^{-1}$, the other $667 \mathrm{U} \mathrm{ml}^{-1}$ ). In order to investigate a colchicine effect, sIL-2R concentrations in two groups of inactive patients who are either on colchicine prophylaxis or not should be compared.

1 Lightfoot RW. Intermittent and periodic arthritic syndromes. In: McCarty DJ, ed. Arthritis and allied conditions,

2 Schattmer A, Lachmi M, Livneh A, Pras M, Hahn T. Tumor necrosis factor in familial Mediterranean fever. $\mathrm{Am} \mathcal{F} \mathrm{Med}$ 1991;90:434-8

3 Rozenbaum M, Katz R, Rozner I, Pollack S. Decreased interleukin-1 activity released from circulating monocytes of patients with familial Mediterranean fever during in vitro stimulation by lipopolysaccharide. $₹$ Rheumatol 1992 19:416-88.

4 Pepys MB. Aspects of acute phase response. The C-reactive protein system. In: Lachman PJ, Peters DK, eds. Clinical aspects of immunology, 4th ed. Oxford: Blackwell Scientific aspects of immunology, 4th
Publications, 1982:50-69.

5 Knecht A, de Beer FC, Pras M. Serum amyloid A protein in familial Mediterranean fever. Ann Intern Med 1985; 102:71-2.

6 Erken E, Demirtas M. Serum amyloid A in familial Mediterranean fever [abstr]. Hungarian Rheumatol 1991; 32(suppl):P1-28

7 Matzner Y, Brzezinski A. C5a inhibitor deficiency in peritoneal fluid from patients with familial Mediterranean fever N Engl f Med 1984;311:287-90.

8 Matzner Y, Patridge RE, Levy M, Babior BM. Diminished activity of a chemotactic inhibitor in synovial fluids from patients with familial Mediterranean fever. Blood 1984, 63:629-99.

9 Ilfeld D, Weil S, Kuperman O. Immunoregulatory abnormalities in familial Mediterranean fever. Clin Immunol Immunopathol 1981;18:261-7. 
10 Oppenheim JJ, Ruscetti FW, Faltynek C. Cytokines. In: Stites P, Terr AI, Parslow TG, eds. Basic and clinical immunology, 8th ed. Northwalk: Appleton and Lange, 1994:105-23.

11 Matsumoto T, Iwasaki K. Clinical and laboratory parameterseters which effect soluble interleukin-2 receptor levels in the serum and synovial fluids of patients with rheumatoid arthritis. Ann Rheum Dis 1993;52:876-80.

12 Keystone EC, Snow KM, Bombardieri C, Chang C, Nelson Keystone EC, Snow KM, Bombardieri C, Chang C, Nelson DL, Rubin LA. Elevated soluble interleukin-2 receptor levels in the sera and synovial fluids of patients with theu-

13 Campen DH, Horwitz DA, Quismorio FP, Ehresmann GR, Martin WJ. Serum levels of interleukin-2 receptor and activity of rheumatic diseases characterized by immune system activation. Arthritis Rheum 1988;31:1358-63.

14 Wolf RE, Brelsford WG. Soluble interleukin-2 receptors in systemic lupus erythematosus. Arthritis Rheum 1988; 31:729-35.

15 Lansbury J, Haut DD. Quantification of the manifestations of rheumatoid arthritis. 4. Area of joint surfaces as an index to total joint inflammation and deformity. Am $\mathcal{F} M e d$ Sci 1956;232:150-5.

16 Melamed A, Cabili S, Zakuth V, Spirer Z. The immune regulation in familial Mediterranean fever (FMF). $\mathcal{f}$ Clin Lab Immunol 1988;26:125-8. 